\title{
Interest in Science: A Comparative Analysis of the Aims of School Science Syllabi
}

\author{
Davis Jean Baptiste \\ University of Newcastle, NSW, Australia \\ David H. Palmer \\ University of Newcastle, NSW, Australia \\ Tel: 612-4921-5715Ｅ-mail: David.Palmer@newcastle.edu.au \\ Jennifer Archer \\ University of Newcastle, NSW, Australia
}

Received: November 5, 2017 Accepted: November 20, 2017 Published: December 5, 2017

doi:10.5296/gjes.v3i2.12107 URL: https://doi.org/10.5296/gjes.v3i2.12107

\begin{abstract}
There is currently worldwide concern about the decline in students' interest in science. The purpose of this paper is to examine school science curriculum documents to determine whether they explicitly state that they aim to enhance student interest in science. A document analysis was used to compare science syllabi from Canada, Finland, Sweden, UK, USA, Hong Kong, Thailand, Singapore, the Eastern Caribbean states, and Hungary. It was found that about half of these countries did have an explicit aim of enhancing student interest in science at high school level. The remainder either did not have any such aim, or had a partial or implied expectation. These findings were then compared to the results of the international PISA 2006 survey of student interest in science. It was found that those countries in which science curriculum documents made no mention about enhancing student interest (Canada and UK) were below the OECD average for interest in science. However, there were other countries below the OECD average, that did have a curriculum aim to enhance student interest in science. It is concluded that having a stated aim to enhance student interest in science is not enough, by itself, to bring that aim to fruition.
\end{abstract}

Keywords: Student interest, Science, Syllabus, Comparative 


\section{Introduction}

Students' perceptions toward science learning have been a subject of much concern among educationalists. Many countries are now seeing record numbers of students, at university level as well as high school, not opting to pursue the sciences. Danaia, Fitzgerald, and McKinnon (2013) reported, "Over the last two decades, in a number of developed countries, there has been a growing concern about both the waning interest many high school students display towards science at school and the declining number of students pursuing science in the post-compulsory years of secondary education" (p. 1502).

This problem is important because of its impact on society. Wilson and Mack (2014) argued that the downward trend in science participation by high school students meant that prospective science teachers are also on the decline. Lyons and Quinn (2010) argued that it would reduce the scientific literacy of the population and the numbers of science specialists available to help solve science-related issues in society.

Declining interest in science has been proposed to be one of the main causes of this problem. Croxford (2002) stated:

We are currently in a paradoxical situation. While science and technology play key roles in today's global economy, young people are turning away from science subjects. Clearly, raising interest in science among young people is necessary for increasing the number of future science professionals. (p. 11)

While the problem of declining interest in science is presently of worldwide concern, not all countries are equally affected. The PISA (Programme for International Student Assessment) survey was first held in 2000, with the support of the OECD (Organisation for Economic Co-operation and Development) and has been carried out every three years since then. In 2006, science was the main focus and the survey provided information not only about students' knowledge and application of science, but also about their interest in science. The survey gathered data from 15-year-old students in 57 countries. The survey included an "Interest in Learning Science Topics" scale which covered broad science areas including plants, human biology, geology, physics, astronomy, and chemistry. The results for this scale were reported on the PISA website (OECD, 2007). It showed that many western countries such as the UK, Canada, and Finland were below the OECD average for this scale, whereas students from Hungary, Hong Kong, and Thailand reported levels of interest in science that were above the OECD average.

In general, the issue of declining interest in science has important implications for the teaching of science in schools. Ideally, all science teachers should strive to promote a positive interest in science among students, and importantly, this should be prioritized in the school science curriculum. The significance of the school curriculum cannot be underestimated as it is the document that guides how science is meant to be implemented in each country. Thus, one of the aims of the school science curriculum should be to enhance students' interest in science. In Australia, for example, one of the Aims of the National Curriculum (Australian Curriculum Assessment and Reporting Authority, 2015) is, 
"To ensure that students develop an interest [emphasis added] in science as a means of expanding their curiosity and willingness to explore, ask questions about and speculate on the changing world in which they live (p.4)".

Thus, this syllabus also implies that teachers would be required to teach in such way that will help instill positive interest in science among their students. For comparative purposes, it is worth considering whether the Australian curriculum is unusual in its emphasis on enhancing interest. In this paper, a sample of science curricula from other countries will be examined in order to determine whether they explicitly aim to promote a positive interest in science. However, it cannot be assumed that interest in science will be enhanced among the majority of students in a country even if it is an explicitly stated aim of the science syllabus. For this reason, it was decided that this study should also refer to the PISA 2006 results, as these would provide information about the comparative levels of interest in science among school students. In this way, it would be possible to not only compare the stated aims of syllabus documents for enhancing interest in science, but also to compare the effectiveness with which those aims have been met in practice. Interestingly, Australian students (mean score 465) were well below the OECD average (500). This suggested that in spite of being an explicit aim of the syllabus, Australian students have had relatively low levels of interest in science.

The objective of this study was to identify syllabus documents that do or do not have an explicit aim of enhancing interest in science, and to compare these with PISA 2006 reported levels of interest in science. For each country, the research questions were:

1) Is enhancing student interest in science an explicit aim of the science curriculum?

2) Does having an explicit aim to enhance interest in science correlate with actual levels of interest in science as measured by the PISA 2006 survey?

\section{Methodology}

This study used a comparative content analysis methodology (Pershing, 2002). In social science research, content analysis can be used to identify patterns of data in a systematic and replicable manner (Allen \& Bell, 2011). This approach involves the systematic observation of written material in order to identify the presence of meaningful patterns. The identification of key words is usually used to code these patterns. To enhance the reliability of the study, the content analysis focused on identifying the terms "interest" or "interest in science". In cases where these terms could not be found, then related terms such as "attitudes" were sought in the documents. In this way, a standardized approach was used for each document.

The study was carried out by performing a content analysis of school science curriculum documents that are available online, and in English language format. A sample of 10 countries were included, namely Canada, Finland, Sweden, UK, USA, Hong Kong, Thailand, Singapore, the Eastern Caribbean states, and Hungary. Thus this sample included western and non-western countries, some of which were above the OECD average for interest in science and others which were below the OECD average for interest in science.

An English version of the lower secondary science curriculum was accessed for each country. 
The syllabus Aims section was first examined in order to identify any explicit mention of student interest in science. If such a statement was not apparent from the Aims section then other sections of the document were studied for statements regarding interest in science.

Finally, for comparative purposes, the scores for the Interest in Learning Science Topics scale were obtained for each of the countries in this study that had also been included in the PISA 2006 study, namely Canada, Finland, Sweden, UK, USA, Hong Kong, Thailand, and Hungary. This study also included two additional countries, Singapore and the Eastern Caribbean states, which had not been part of the PISA 2006 study.

\section{Results}

In the secondary science syllabus in Hong Kong (Curriculum Development Council, 1998) one of the general Aims is that students should "develop curiosity and interest in science" (p.5). Thus, the development of student interest is an explicit component of the science curriculum in Hong Kong. It is worth noting that in the PISA 2006 Interest in Learning Science Topics scale, the Hong Kong mean of 536 was above the OECD average of 500.

The secondary science syllabus in Singapore (Ministry of Education, 2012), states that science,

Involves stimulating the students' curiosity, interest and enjoyment in science and matters relating to science and technology as well as developing the students' interest and care for the environment (p. 5).

Thus, the science syllabus in Singapore is explicit in stating that enhancing interest in science is a key aim.

In Thailand, the Basic Education Core Curriculum, (The Ministry of Education, Thailand. 2008), it is stated that,

The learning area of science is aimed at enabling learners to learn this subject with emphasis on linking knowledge with processes, acquiring essential skills for investigation, building knowledge through investigative processes, seeking knowledge and solving various problems. (p. 108).

Although this general statement did not explicitly mention interest in science, the Grade 9 curriculum stated that students should "Show interest, determination, responsibility, care and honesty in investigating and seeking knowledge" (p. 110). Thus this curriculum does mention student interest. Interestingly, Thailand's score in the Interest in Learning Science Topics scale (OECD, 2007) was 642, which was well above the OECD average of 500. In fact it was the second highest score in that survey.

In the USA's National Science Education Standards (National Research Council, 1996) it is not explicitly stated that interest in science should be enhanced. Instead, the term "attitudes" is used throughout. For example, it is stated that "the attitudes and values established toward science in the early years will shape a person's development of scientific literacy as an adult" (p.22), and that teachers need to develop "Certain attitudes, such as wonder, curiosity, and 
respect toward nature" (p. 50) among the students. Furthermore, "those attitudes are reinforced when the adults in the community engage in their own learning and when they share positive attitudes toward science" (p. 50). Thus, there is no explicit mention of developing an interest in science in this document, although it should be noted that an attitude toward science could include an interest in science: Osborne et al. (2003) for example, argued that attitudes towards science would include "the feelings, beliefs and values held about an object which may be the enterprise of science, school science, the impact of science on society or scientists themselves..." (p. 6). In this way, having an interest in science can be considered a type of attitude towards science. Interestingly, the USA score in the Interest in Learning Science Topics scale (OECD, 2007) was 480, which was below the OECD average of 500 .

The Organization of Eastern Caribbean States (OECS) has developed a joint science curriculum for the island nations that make up the Eastern Caribbean. The syllabus is designed to encourage the development of positive attitudes in science. Although the term "attitudes" is used, this curriculum does not clarify whether they should be interpreted as "attitudes towards science" (i.e., liking science) or "science-related attitudes" (i.e., objectivity, perseverance, logical thought). For example, in the secondary science curriculum, it is stated that,

The purpose of developing the learning outcomes and instructional modules is to ensure that all children in OECS primary schools attain an acceptable level of knowledge, skills and attitude associated with science and technology. Each member country retains the right and responsibility for integrating these outcomes into the national lower secondary science and technology curriculum (Hinds, 2007, pp. 3-4).

Thus, the science syllabus for the Eastern Caribbean states does not refer specifically to the development of student interest, and it is unclear how to interpret the term attitudes as used in this document.

In Finland National Core Curriculum (National Board of Education, 2003) states that biology Instruction "will develop students' scientific thinking, arouse their interest in the life sciences and encourage them to behave in an environmentally responsible manner" (p. 134). Similarly, the objectives of instruction in chemistry are "To obtain experiences that will arouse and intensify their interest in chemistry and chemistry studies (P. 156). However, the objectives of instruction in physics do not contain any statements about interest. Instead, there are statements such as "Become aware of humans as part of nature and understand the significance of physics in modelling natural phenomena" (p. 148). Thus the Finnish curriculum is unusual in that developing interest is an explicit component of the Biology curriculum and the chemistry curriculum but not the physics curriculum. Interestingly, the Finland score in the Interest in Learning Science Topics scale (OECD, 2007) was 448, which was well below the OECD average of 500 .

In Canada, the Ontario Curriculum for grades 9 and 10 Science (Ministry of Education Ontario, 2008) states that the three goals of the science program are: 
1) To relate science to technology, society and the environment

2) To develop the skills, strategies and habits of mind required for scientific inquiry.

3) To understand the basic concepts of science (p. 4)

Thus, the development of interest in science is not an explicit component of this curriculum. The terms "habits of mind" as used in these aims does not appear to include an interest in science, rather it refers to "a commitment to accuracy, precision, and integrity in observation, respect for evidence, adherence to safety procedures; and respect for living things and the environment" (p. 8). Thus, this document does not contain explicit or implied mention of developing students' interest in science. Interestingly, the Canada score in the Interest in Learning Science Topics scale (OECD, 2007) was 469, which was below the OECD average of 500 .

In Sweden, the Curriculum for the Compulsory School, Preschool Class and the Leisure Time Centre (National Agency for Education, 2010) has the following aims for science studies. First, "Teaching in biology should aim at helping the students to develop knowledge of biological contexts, and their curiosity and interest in getting to know more about themselves and nature" (P. 105). Second, "Teaching in physics should aim at helping the pupils to develop knowledge of the contexts of physics and their curiosity and interest in studying the surrounding world" (p. 120). Third, "Teaching in chemistry should aim at helping the pupils to develop knowledge of the contexts of chemistry and their curiosity and interest in investigating the surrounding world" (p. 135). Thus, the development of student interest in science is an explicit aim of this curriculum. Interestingly, the Sweden score in the Interest in Learning Science Topics scale (OECD, 2007) was 454, which was well below the OECD average of 500 .

In the United Kingdom (UK), the science programmes of study for the national curriculum in England (Department of Education, 2013) state that "science aims to ensure that all pupils:

Develop scientific knowledge and conceptual understanding through the specific disciplines of biology, chemistry and physics;

Develop understanding of the nature, processes and methods of science through different types of science inquiries that help them to answer scientific questions about the world around them;

Are equipped with the scientific knowledge required to understand the uses and implications of science, today and for the future (p. 3).

There is no explicit mention of developing an interest in science in this document. Interestingly, the UK score in the Interest in Learning Science Topics scale (OECD, 2007) was 464, which was well below the OECD average of 500.

In Hungary, the National Core Curriculum (Ministry of Education and Culture, 2007) describes the competencies that students should develop in natural science, as follows,

Competencies in science equally presuppose a critical and curious attitude, interest in 
issues of ethics and respect for safety and sustainability, in particular with regard to the impact scientific and technological development has on us, our families, community and the Earth" (p. 6).

This document does use the word interest in relation to "issues of ethics", but it does not make mention of developing an interest in science. Interestingly, the Hungary score in the Interest in Learning Science Topics scale (OECD, 2007) was 522, which was comfortably above the OECD average of 500 .

\section{Discussion}

The syllabi examined here show considerable variation in the extent to which the enhancing of student interest in science is explicitly stated. The science syllabi from Hong Kong, Thailand, Singapore, and Sweden explicitly stated that enhancing student interest in science was one of the main aims. However, it is also important to consider the ways in which these aims might be implemented. In the Swedish system for example, previous studies have identified the use of approaches involving environmental issues, inquiry skills, and holistic comprehension as being associated with science interest and attitudes (Chang, Rundgren, \& Rundgren, 2017). Furthermore, it has been reported that inquiry leaning underpins the primary science syllabus in Singapore and that this approach can support enhanced interest in science (Jocz, Zhai, \& Tan, 2014).

Other curricula, including those from Finland, USA, and Hungary appeared to imply partial support for the idea of enhancing student interest in science. It is notable that previous studies (e.g., Hundal, Levin, \& Keselman, 2014) have argued that the science curriculum in the USA context would be enhanced by the inclusion of environmental health integration and greater use of argumentation. In addition, Merolla and Serpe (2013) have argued that the use of STEM enrichment programs could be used alongside the curriculum to enhance interest in science in the USA.

Finally, the curricula from Canada, UK, and the Eastern Caribbean states did not appear to have any expectation that teachers should aim to enhance student interest in science. Interestingly, Woodward and Woodward (1998) studied elementary school students in Wales and reported that the National Curriculum in the UK appeared to have had a small but positive impact on student attitudes towards science. However, Millar (2006) reported that an emphasis on scientific literacy could enhance student interest in science in the UK to a greater extent.

Some interesting patterns were found when the requirements of the curriculum documents were compared to the PISA 2006 results for students' self-reported interest in science. The countries that were above the OECD average on the Interest in Learning Science Topics scale were Hong Kong, Thailand, and Hungary, and each of these did make at least some mention of the aim of enhancing student interest. However, a more complex pattern emerged for those countries that were below the OECD average. Some of these countries, such as Finland, Sweden, Australia, and USA had some stated aim to enhance interest (or attitude) towards science. McConney, Oliver, Woods-McConney, Schibeci, and Maor (2014) provided a 
possible explanation for this anomaly, at least in the Australian context, as they reported that lower levels of inquiry-oriented learning activities resulted in lower levels of interest in science; and this implies that these types of activities were not being implemented in schools to the extent that one would hope. Other curricula however, such as those from Canada and the UK, made no explicit mention of enhancing interest as a priority for science.

\section{Conclusions}

These findings suggest that if the science syllabus has an explicitly stated aim of enhancing student interest in science, it will not necessarily result in students in that country having an enhanced interest in science. However, it should be noted that those countries that clearly made no mention of the term "interest" in their syllabus documents, namely Canada and UK, were both below the OECD average for interest in science. On this basis, there may be some value in including the development of student interest in science as an explicit aim of the science syllabus. An important issue however, is that the way the curriculum is implemented can play a major role in determining its effects on student interest in science.

This study had some limitations that should be considered when interpreting its findings. First, this analysis used the PISA 2006 results as the basis for determining interest in science, but it is important to emphasize that there are other ways to measure interest in science, and these may not always provide the same results. In the present study however, the PISA results were preferred because they included a wide variety of different countries. A second issue is that many countries do not provide English language versions of their science curricula that are available online. For this reason, it was necessary to restrict the study to the countries mentioned above.

\section{References}

Alan, B., \& Bell, E. (2011). Business research methods. Cambridge: Oxford University Press.

Australian Curriculum Assessment and Reporting Authority. (2015). The Australian Curriculum Science. $\quad$ Retrieved from https://www.australiancurriculum.edu.au/f-10-curriculum/science/

Chang Rundgren, S. N., \& Rundgren, C. J. (2017). What are we aiming for?--A Delphi study on the development of civic scientific literacy in Sweden. Scandinavian Journal of Educational Research, 61, 224-239. https://doi.org/10.1080/00313831.2015.1120231

Croxford, L. (2002). Participation in Science, Engineering and Technology at School and in Higher Education. Edinburgh: Centre for Educational Sociology, University of Edinburgh, Scotland.

Curriculum Development Council. (1998). Syllabuses for Secondary Schools, Science (Secondary 1-3). Retrieved from http://cd1.edb.hkedcity.net/cd/science/is/sci_syllabus_S1to3_e.pdf

Danaia, L., Fitzgerald, M., \& McKinnon, D. (2013). Students' perceptions of high school science: What has changed over the last decade? Research in Science Education, 43(4), 
1501-1515. https://doi.org/10.1007/s11165-012-9318-X

Department of Education. (2013). The National Curriculum in England. Retrieved from https://www.gov.uk/.../national-curriculum-in-england-science-programmes-of-study

Finnish National Board of Education. (2003). The National Core Curriculum (Finland). Retrieved from http://www.oph.fi/download/47678_core_curricula_upper_secondary_education.pdf

Hinds, H. (2007). OECS Curriculum Harmonization Science and Technology Grades K-6. Retrieved from https://vincyclassroom.files.wordpress.com/2012/01/learning-outcomes.pdf

Hundal, S., Levin, D. M., \& Kesselman, A. (2014). Lessons of researcher-teacher co-design of an environmental health afterschool club curriculum. International Journal of Science Education, 36, 1510-1530. https://doi.org/10.1080/09500693.2013.844377

Jocz, J. A., Zhai, J., \& Tan, A. L. (2014). Inquiry learning in the Singaporean context: Factors affecting student interest in school science. International Journal of Science Education, 36, 2596-2618. https://doi.org/10.1080/09500693.2014.908327

Lyons, T., \& Quinn, F. (2010). Choosing Science: Understanding the Declines in Senior High School Science Enrolments. National Centre of Science, ICT and Mathematics Education for Rural and Regional Australia (SiMERR Australia), Australia.

McConney, A., Oliver, M. C., Woods-McConney, A., Schibeci, R., \& Maor, D. (2014). Inquiry, engagement, and literacy in science: A retrospective, cross-national analysis using PISA 2006. Science Education, 98, 963-980. https://doi.org/10.1002/sce.21135

Merolla, D. M., \& Serpe, R. T. (2013). STEM enrichment programs and graduate school matriculation: The role of science identity salience. Social Psychology of Education: An International Journal, 16, 575-597. https://doi.org/10.1007/s11218-013-9233-7

Millar, R. (2006). Twenty first century science: Insights from the design and implementation of a scientific literacy approach in school science. International Journal of Science Education, 28, 1499-1521. https://doi.org/10.1080/09500690600718344

Ministry of Education and Culture, Hungary. (2007). The National Core Curriculum. Retrieved from www.ibe.unesco.org/curricula/hungary/hu_al_fw_2007_eng.pdf

Ministry of Education, Singapore. (2013). Science Syllabus Primary. Curriculum Planning and Development Division. Retrieved from https://www.moe.gov.sg/docs/defaultsource/document/education/syllabuses/sciences/files/sci ence-primary-2014.pdf

Ministry of Education, Thailand. (2008). The Basic Education Core Curriculum. Retrieved from www.act.ac.th/document/1741.pdf

Ministry of Education. (2008). Ontario Curriculum for grades 9 and 10 Science. Retrieved from www.edu.gov.on.ca/eng/curriculum/secondary/science910_2008.pdf 


\section{Macrothink}

Global Journal of Educational Studies

ISSN 2377-3936 2017, Vol. 3, No. 2

National Agency for Education. (2010). The Curriculum for the Compulsory School, Preschool Class and the Leisure Time Centre. Retrieved from modersmal.skolverket.se/engelska/images/stories/filer/pdf2687.pdf

National Research Council. (1996). National Science Education Standards. Washington DC. USA: The National Academies Press.

OECD (Organisation for Economic Cooperation and Development). (2007). PISA 2006: Science Competencies for Tomorrow's World. Retrieved from http://www.oecd.org/edu/school/programmeforinternationalstudentassessmentpisa/pisa2006re sults.htm

Osborne, J., Simon, S., \& Collins, S. (2003). Attitudes towards science: A review of the literature and its implications. International Journal of Science Education, 25(9), 1049-1079. https://doi.org/10.1080/0950069032000032199

Pershing, J. L. (2002). Using document analysis in analyzing and evaluating performance. Performance Improvement, 41, 36-42. https://doi.org/10.1002/pfi.4140410108

Wilson, R., \& Mack, J. (2014). Declines in high school mathematics and science participation: Evidence of students' and future teachers' disengagement with maths. International Journal of Innovation in Science and Mathematics Education, 22(7), 35-48.

Woodward, C., \& Woodward, N. (1998). Welsh primary school leavers' perceptions of science. Research in Science and Technological Education, 16, 43-52. https://doi.org/10.1080/0263514980160104

\section{Copyright Disclaimer}

Copyright for this article is retained by the author(s), with first publication rights granted to the journal.

This is an open-access article distributed under the terms and conditions of the Creative Commons Attribution license (http://creativecommons.org/licenses/by/3.0/). 